\title{
Pengembangan bahan ajar teks PPKn berbasis discovery learning untuk meningkatkan pengetahuan warga negara siswa sekolah menengah atas
}

\author{
Lina Marlina ${ }^{1}$, Aryanti Dwi Untari ${ }^{2}$ \\ 1,2 Program Studi Pendidikan Pancasila dan Kewarganegaraan, Universitas Banten Jaya, Banten, Indonesia
}

\begin{abstract}
ABSTRAK
Penelitian ini bertujuan untuk mengembangkan bahan ajar melalui buku Teks PPKn untuk meningkatkan pengetahuan warga negara yang berbasis discovery learning penelitian pengembangan ini melalui pembuatan desain awal bahan ajar, pengujian ahli, revisi sesuai saran dan kritik para ahli, pengujian skala terbatas, serta revisi sesuai hasil uji skala terbatas. Uji skala terbatas dilakukan pada siswa kelas XI SMA Maulana Yusuf Kota Serang. Penelitian ini menggunakan metode penelitian dan pengembangan. Metode ini digunakan untuk menghasilkan produk tertentu dan menguji keefektivan produk tersebut, dengan menggunakan tiga tahapan meliputi 1) model pengembangan, 2) prosedur pengembangan, 3) uji coba produk, dan prosedur pengembangan yang akan ditempuh merujuk pada prosedur pengembangan yang dilakukan oleh borg dan gall yaitu pengembangan pembelajaran mini (mini course). Hasil akhir penelitian ini diharapkan dapat memberikan informasi kontribusi bahan ajar berupa buku teks PPKn kelas XI agar pada saat proses pembelajaran siswa dapat dengan mudah menyerap materi agar kompetensi siswa di bidang pengetahuan warga negara dapat meningkat.
\end{abstract}

\section{Sejarah Artikel}

Diterima: 02 Oktober2019

Disetujui: 16 April 2020

\section{Kata kunci:}

Bahan Ajar, Buku Teks PPKn, Pembelajaran Discovery, Pengetahuan Warga Negara

\section{Keywords: \\ Teaching Materials, PPKn Textbook, Discovery Learning, Civic}

\begin{abstract}
This study aims to develop teaching materials through the PPKn Textbook to increase citizen knowledge based on discovery learning. This research development through the initial design of teaching materials, expert testing, revisions according to expert suggestions and criticisms, limited-scale testing, and revisions according to test results limited scale. The limited scale test conducted on the tenth-grade students of Maulana Yusuf High School in Serang City. This research uses research and development methods. This method is used to produce specific products and test the effectiveness of these products, using three stages, including 1) development models, 2) development procedures, 3) product trials, and development procedures to be adopted refer to the development procedures carried out by Borg and Gall. Namely, the development of mini learning (mini-courses). The final results of this study expected to provide information on the contribution of teaching materials in the form of class XI PPKn textbooks so that during the learning process, students can easily absorb material so that students' competencies in the field of citizen knowledge can increase.
\end{abstract}

\section{Pendahuluan}

Tujuan Pendidikan Pancasila dan Kewarganegaraan (PPKn) menunjukan bahwa dari segi pengetahuan, sikap, dan keterampilan serta pembentukan karakter siswa perlu adanya kompetensi yang meliputi kompetensi sikap, pengetahuan, dan keterampilan. Dalam proses pembelajaran PPKn, ada tiga kompetensi yang disebut juga dengan pengetahuan warga negara (civic knowledge), sikap warga negara (civic dipositions), dan keterampilan warga negara (civic skill). Kompetensi tersebut sangatpenting dalam kehidupan bermasyarakat untuk menciptakan warga Negara yang baik terutama di dunia pendidikan siswa dapat menjadi warga negara yang baik, di lingkungan keluarga, masyarakat dan Negara. Civic knowledge merupakan pengetahuan dasar untuk dapat mengembangkan civic dipositions dan civic skill. Prorposi civic knowledge mencakup 25\% pengetahuan, 75\% analisa dan penalaran (Schulz, W., Ainley, J., Fraillon, J., Kerr, D., \& Losito, 2009). Ini menunjukan jika PPKn tidak hanya berfokus pada teori semata, namun harus dengan praktik. (Alivernini \& Manganelli, 2011). Namun juga dalam penelitian lain dalam 
pembelajaran PPKn di kelas, dimensi moral dalam mengajar kewarganegaraan cukup menonjol (Althof \& Berkowitz, 2006; Sanger \& Osguthorpe, 2013). Misalnya guru sebagai pribadinya sendiri ,merupakan role model bagi siswa melalui interaksi mereka dengan siswa (Willemse et al., 2015), dan melalui apa yang mereka tekankan ketika mereka mengajar pengetahuan dan keterampilan khusus yang bernilai (Torney-Purta \& Barber, 2004; Willemse et al., 2015). Profesionalisme guru setidaknya sebagian tergantung pada nilai-nilai, kepercayaan, pengetahuan dan keterampilan pribadi dan profesional yang guru mungkin tidak sepenuhnya sadari (Husu \& Tirri, 2007; Kennedy et al., 2009; Patterson et al., 2012). Dengan demikian, seringkali guru melakukan kegiatan pembelajaran secara tidak terencana tanpa kompetensi yang memadai (Thornberg, 2008; Willemse et al., 2015). Maka untuk mencapai tujuan dari belajar diperlukan strategi pembelajaran dan bahan ajar yang memadai yang merupakan salah satu unsur yang dapat menciptakan kondisi lingkungan belajar bagi siswa.

Bahan ajar adalah seperangkat sarana atau alat pembelajaran yang berisikan materi pembelajaran, metode, batasan-batasan, dan cara mengevaluasi yang didesain secara sistematis dan menarik membantu guru atau instruktur dalam rangka mencapai tujuan yang diharapkan, yaitu mencapai kompetensi atau subkompetensi dengan segala kompleksitasnya (Hasanah, 2018; Widodo \& Jasmadi, 2008). Bahan yang dimaksud dapat berupa bahan ajar tertulis maupun tidak tertulis. Pandangan dari ahli lainnya mengatakan bahwa bahan ajar adalah seperangkat materi yang disusun secara sistematis, baik tertulis maupun tidak tertulis, sehingga tercipta lingkungan atau suasana yang memungkinkan peserta didik untuk belajar (Prastowo, 2011).

Bahan ajar merupakan materi pembelajaran yang disampaikan guru kepada siswa, sehingga diperlukan bahan ajar yang mampu mewadahinya. Bahan ajar mempengaruhi keberhasilan peserta didik dalam proses belajar selain peranan seorang guru, maka dari itu perlu dirumuskan bahan ajar yang mampu mendukung terselenggarakannya pendidikan yang baik, khususnya dalam hal ini adalah mata pelajaran PPKn. Kesesuaian antara kompetensi yang hendaknya dicapai dengan bahan ajar yang tersedia. Idealnya materi pembelajaran harus relevan dengan kompetensi yang dibutuhkan, materi esensial, dan sesuai dengan tingkat perkembangan anak (Wijayanti \& Zulaeha, 2015). Salah satu kompetensi dasar pembelajaran yang termuat dalam Kurikulum 2013 adalah keterampilan memproduksi teks.

Dari sudut pandang teori semiotika sosial, teks merupakan suatu proses sosial yang berorientasi pada suatu tujuan sosial. Tujuan sosial yang hendak dicapai memiliki ranah-ranah pemunculan yang disebut konteks situasi. Proses sosial akan berlangsung jika terdapat sarana komunikasi yang disebut bahasa (Mahsun, 2013). Teks dimaknai sebagai aturan bahasa yang mengungkapkan makna secara kontekstual. Struktur teks merupakan cerminan struktur berpikir. Makin banyak jenis teks yang dikuasai peserta didik, makin banyak pula struktur berpikir yang dapat digunakannya dalam kehidupan sosial dan akademiknya (Wijayanti \& Zulaeha, 2015). Penggunaan bahan ajar sampai saat ini masih sedikit yang memuat pendidikan karakter (Prastowo, 2011) menyatakan bahwa kenyataan dalam praktik pendidikan banyak pendidik yang masih menggunakan bahan ajar yang yang sudah tersedia tanpa memeriksa kelayakannya atau merencanakan, menyiapkan, dan menyusunnya sendiri sehingga risikonya dimungkinkan bahan ajar yang mereka pakai tidak kontekstual, tidak menarik, monoton, dan tidak sesuai dengan kebutuhan peserta didik. Berkaitan dengan hal tersebut di atas, perlu juga dirumuskan materi bahan ajar yang mengakomodasi dua hal tersebut, yaitu (a) penyampaian substansi meteri bahan ajar yang sesuai dengan mata pelajaran yang diajarkan, dan (b) mampu menjadi wadah pengembangan nilai-nilai budi pekerti khususnya pada aspek kesantunan. Oleh karena itu diperlukan bahan ajar yang memperhatikan upaya membangun budi pekerti khususnya aspek 
kesantunan dalam kepribadian peserta didik yang dapat pula meningkatkan hasil capaian peserta didik.

Penelitian ini dilaksanakan di SMA Maulana Yusuf Kota Serang kelas XI yang bertujuan untuk dapat membuat serta mengembangkan Bahan ajar berupa buku teks mata pelajaran PPKn di sekolah tersebut. Penelitian ini dilaksanakan pada bulan April 2019 sampai dengan November 2019. Penelitian ini terdiri dari dua topik utama yaitu pembuatan serta pengembangan bahan ajar buku teks PPKn berbasis discovery learning dan untuk meningkatkan civic knowledge siswa. Bahan ajar atau lebih dikenal dengan buku pendamping merupakan salah satu sumber bahan ajar ilmu pengetahuan, informasi, dan hiburan yang dapat diperoleh dari bahan ajar tersebut. Penelitian pengembangan ini melalui pembuatan desain awal bahan ajar, pengujian ahli, revisi sesuai saran dan juga masukan dari para ahli, serta adanya pengujian skala terbatas dan hasil dari pengujian skala terbatas. Uji skala terbatas dilakukan pada siswa kelas XI SMA Maulana Yusuf Kota Serang.

Studi pendahuluan dilakukan untuk dapat melihat pembelajaran PPKn di sekolah SMA Maulana Yusuf Kota Serang. Para guru terutama Guru PPKn menggunakan buku sebagai pusat sumber belajar. Guru mengatakan bahwa para siswa masih kesulitan dalam memahami materi pada pembelajaran PPKn. Selain itu juga masih menggunakan metode pembelajaran yang monoton seperti siswa hanya mendengarkan guru saja, sekolah ini adalah swasta yang mengalami perubahan kurikulum dari KTSP kurikulum 2006 ke kurikulum 2013, sehingga guru masih kurang memahami kurikulum yang baru dan aktivitas belajar masih menggunakan metode yang hanya menjelaskan dan mendengarkan atau sering di sebut dengan metode ceramah dan isi materi yang terdapat di bahan ajar buku teks siswa masih kesulitan dalam memahaminya.

Penelitian ini menggunakan pendekatan berbasis discovery learning yang dapat digunakan untuk mengembangkan bahan ajar, pada pendekatan ini akan menjadi salah satu cara untuk mengatasi permasalahan yang terjadi dengan adanya inovasi dari bahan ajar berupa buku teks sehingga siswa akan dengan mudah memahami apa yang akan di pelajari. Tujuan pada penelitian kali ini adalah peneliti ingin mengembangkan bahan ajar di sekolah SMA Maulana Yusuf Kota Serang menjadi sebuah pengembangan bahan ajar yang dapat di terima dan dapat di gunakan oleh guru PPKn dan para siswa agar pada proses belajar mengajar guru dan siswa mendapatkan pemberharuan sebuah pengembangan bahan ajar yang akan di gunakan bahan ajar buku teks PPKn berbasis discovery learning akan memberikan siswa pemahaman materi yang lebih mudah untuk dapat di pahami yang berkaitan dengan materi kewarganegaraan.

Untuk mengatasi permasalah yang terjadi pada Siswa di SMA Maulana Yusuf Kota Serang dan dari permasalahan tersebut diantaranya siswa masih kesulitan dalam memahami materi pada mata pelajaran PPKn, guru masih menggunakan metode pembelajaran yang monoton serta guru masih belum memahami kurikulum yang baru. Oleh karena itu peneliti berupaya untuk dapat mengembangkan bahan ajar PPKn melalui pembuatan bahan ajar yang dilakukan oleh peneliti guna meningkatkan civic knowledge siswa di SMA Maulana Yusuf Kota Serang. Tujuan pada penelitian kali ini adalah peneliti ingin mengembangkan bahan ajar yang dibuat dan disusun oleh peneliti di sekolah SMA Maulana Yusuf Kota Serang menjadi sebuah pengembangan bahan ajar yang dibuat serta dapat di terima dan dapat di gunakan oleh guru PPKn dan para siswa agar pada proses belajar mengajar guru dan siswa mendapatkan pembaharuan pada proses pembelajaran dengan adanya sebuah pengembangan bahan ajar yang dibuat oleh peneliti akan di gunakan oleh guru dan siswa maka bahan ajar buku teks PPKn berbasis discovery learning akan memberikan siswa pemahaman materi yang lebih mudah untuk dapat di pahami yang berkaitan dengan materi kewarganegaraan.

Penelitian dilakukan diawali dengan menyusunan draft produk, pembuatan produk kemudian pada tahap model pengembangan yang dilanjutan pada prosedur penelitian 
pengembangan kemudian dilakukan uji coba produk. Pentingnya penelitian kali ini dilakukan bahwa peneliti menganggap ini sebagai sarana penting untuk dapat meningkankan civic knowledge siswa kelas XI di SMA Maulana Yusuf Kota Serang pada pembelajaran PPKn dengan adanya pengembangan bahan ajar yang di gunakan. Penelitian kali ini menggunakan metode penelitian dan pengembangan (Research and Development) dengan menggunakan tiga tahapan meliputi 1) model pengembangan, 2) prosedur pengembangan, 3) uji coba produk, dan prosedur pengembangan yang akan ditempuh merujuk pada prosedur pengembangan yang dilakukan oleh Borg dan Gall yaitu pengembangan pembelajaran mini.

\section{Metode}

Metode yang digunakan adalah metode penelitian dan pengembangan (Research and Development). Menurut (Sugiyono, 2010), metode penelitian dan pengembangan digunakan untuk menghasilkan produk tertentu dan menguji keefektivan produk tersebut. Model penelitian dan pengembangan yang digunakan mengikuti langkah dari Borg \& Gall dalam (Sugiyono, 2010) yang terdiri atas 10 langkah yaitu: (1) research and information collecting (melakukan pengumpulan informasi), (2) planing (melakukan perancangan), (3) develop preliminary form of product (mengembangkan bentuk produk awal), (4) preliminary field testing (melakukan uji coba kelompok kecil), (5) main product revision (melakukan revisi terhadap produk utama), (6) main field testing(melakukan uji coba lapangan), (7) operasional product revision (melakukan revisi terhadap uji lapangan), (8) operasional field testing (melakukan uji pelaksanaan lapangan), (9) final product revision (melakukan revisi terhadap produk akhir), (10) dissemination and implementation (mendesiminasikan dan mengimplementasikan produk). Penelitian pengembangan memuat 3 komponen, yaitu 1) Model pengembangan, 2) Prosedur Pengembangan, dan 3) Uji Coba Produk (Hasanah, 2018). Penelitian dilakukan diawali dengan menyusunan draf produk, pembuatan produk kemudian pada tahap model pengembangan yang dilanjutan pada prosedur penelitian pengembangan kemudian dilakukan uji coba produk.

\section{Hasil dan Pembahasan}

Pada penelitian ini peneliti membutuhkan Alat-alat yang digunakan dalam penelitian ini adalah Buku Pedoman Diklat Pelatihan Kurikulum 2013, Silabus dan RPP Pelajaran PPKn Kelas XI SMA/SMK, dan sumber literatur lain yang menunjang. Sesuai dengan metode penelitian yang menggunakan metode pengembangan untuk menghasilkan produk tertentu dan menguji keefektivan produk penelitian yang digunakan tersebut (Sugiyono, 2010).

Buku teks adalah buku berisi uraian bahan tentang mata pelajaran atau bidang studi tertentu, yang disusun secara sistematis dan telah diseleksi berdasarkan tujuan tertentu, orientasi pembelajaran, dan perkembangan siswa. Manfaat buku teks tidak hanya untuk siswa, tetapi guru pun terbantu dengan kehadiran buku teks. Selain digunakan oleh peserta didik, buku teks digunakan oleh guru pada waktu mengajar seperti yang dikemukakan oleh Muslich (2010) bahwa bahan ajar cetak sebagai bahan ajar yang paling mudah ditemui dan digunakan harus mencermati beberapa komponen yang dapat menunjang peningkatan kemampuan siswa dalam proses pembelajaran.

Pada produk awal bahan ajar cetak berbasis discovery learning yang berintegrasi pada kemampuan siswa untuk meningkatkan civic knowledge pada siswa Kelas XI SMA/SMK. Bahan Ajar Buku Teks yang digunakan pada penelitian kali ini adalah dengan Berbasis Discovery Learning yang didefinisikan sebagai suatu cara mengajar yang melibatkan siswa dalam proses kegiatan mental melalui tukar pendapat, dengan diskusi, seminar, membaca sendiri, agar anak dapat belajar sendiri (Roestiyah, 1991). Dalam pembelajaran discovery (penemuan) kegiatan atau pembelajaran yang 
dirancang sedemikian rupa sehingga siswa dapat menemukan konsep-konsep dan prinsip-prinsip melalui proses mentalnya sendiri. Discovery learning adalah memahami konsep, arti, dan hubungan, melalui proses intuitif untuk akhirnya sampai kepada suatu kesimpulan. Dalam menemukan konsep, siswa melakukan pengamatan, menggolongkan, membuat dugaan, menjelaskan, menarik kesimpulan dan sebagainya untuk menemukan beberapa konsep atau prinsip (Budiningsih, 2015). Setelah itu kemudian akan diuji cobakan oleh ahli pendidikan pancasila dan kewargabnegaraan, ahli pendidikan dan ahli desain yang kemudian akan dianalisa dari hasil angket tersebut, dibawah ini adalah desain awal sampul gabungan bahan ajar mata pelajaran PPKn, yang kemudian akan dikaji kembali oleh ahli bidang uji ahli desain.

Gambar 1

Desain Awal Cover Gabungan Bahan Ajar Mata Pelajaran PPKn

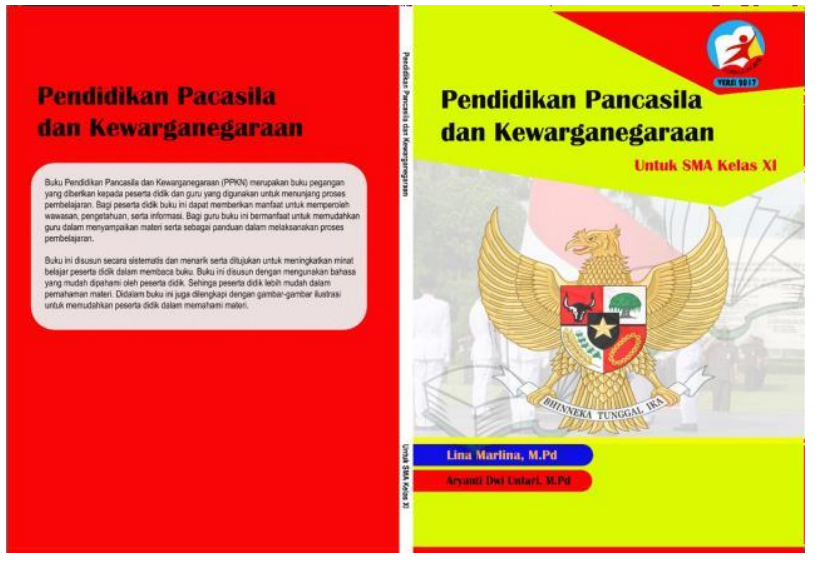

\section{COVER GABUNGAN}

Pengambilan sampel pada penelitian ini adalah untuk memperoleh informasi dari responden mengenai permasalahan yang spesifik atau tidak jelas terlihat di dunia nyata, maka teknik sampling snowball merupakan salah satu cara yang dapat diandalkan dan sangat bermanfaat dalam menemukan responden yang dimaksud sebagai sasaran penelitian melalui keterkaitan hubungan dalam suatu jaringan, sehingga tercapai jumlah sampel yang dibutuhkan. Sampel yang diambil dari penelitian ini adalah dari siswa kelas XI SMA Maulana Yusuf Kota Serang yang berjumlah 20 orang siswa

Dalam penelitian ini yaitu uji coba pada tahap awal terciptanya produk berupa pengembangan bahan ajar buku teks PPKn berbasis discovery leraning untuk meningkatkan civic knowledge siswa SMA Maulana Yusuf Kota Serang dengan kriteria menurut ahli PPKn sebesar 67, $36 \%$, ahli pendidikan sebesar $78 \%$; ahli desain $80 \%$ dan pada uji coba pada tahap selanjutnya kriteria menurut ahli PPKn sebesar 82, 10\%; ahli pendidikan sebesar 84,6\%; ahli desain 86, 1\%.

Analisis data dengan menggunakan instrumen angket. Setelah pengumpulan data dengan angket, maka dilakukan tahap analisis data. Angket tersebut digunakan sebagai instrumen yang bertujuan untuk mengetahui sejauh mana kelayakan produk yang dihasilkan. Angket yang digunakan dalam penelitian ini termasuk angket tertutup dan terbuka. Angket yang disajikan dalam bentuk sedemikian rupa sehingga responden diminta untuk satu jawaban yang sesuai dengan karakterisik diirnya dengan cara memberi tanda silang $(X)$ atau tanda checklist $(\mathrm{V})$. Setiap siswa diminta untuk menjawab pertanyaan-pertanyaan yang diberikan dengan jawaban Sangat Setujuu (SS), Setuju (S), Tidak Setuju (TS), dan Sangat Tidak Setuju (STS). Untuk pertanyaan positif maka dikalikan dengan nilai $S S=4, S=3, T S=2$, Dan $S T S=1$, dan sebaliknya untuk pertanyaan negatif dengan nilai $\mathrm{SS}=1, \mathrm{~S}=2, \mathrm{TS}=3$ dan $\mathrm{STS}=4$. 
Tabel 1

Penilaian Angket Siswa

\begin{tabular}{lcccc}
\hline \multicolumn{1}{c}{$\begin{array}{c}\text { Pernyataan } \\
\text { angket }\end{array}$} & $\begin{array}{c}\text { SS (Sangat } \\
\text { Sering) }\end{array}$ & $\begin{array}{c}\text { S } \\
\text { (sering) }\end{array}$ & J (Jarang) & $\begin{array}{c}\text { TP (Tidak } \\
\text { Pernah) }\end{array}$ \\
\hline $\begin{array}{l}\text { Pernyataan } \\
\text { positif }\end{array}$ & 4 & 3 & 2 & 1 \\
$\begin{array}{l}\text { Pernyataan } \\
\text { negatif }\end{array}$ & 1 & 2 & 3 & 4 \\
\hline
\end{tabular}

Sumber: Data hasil penelitian, 2019

Setalah analisa data dengan menggunakan instrumen angket yang telah di uji cobakan oleh ahli PPKn, ahli pendidikan dan ahli desain maka dibawah ini adalah hasil desain hasil revisi sampul gabungan bahan ajar mata pelajaran PPKn.

Gambar 2

Desain Hasil Revisi Cover Gabungan Bahan Ajar Mata Pelajaran PPKn

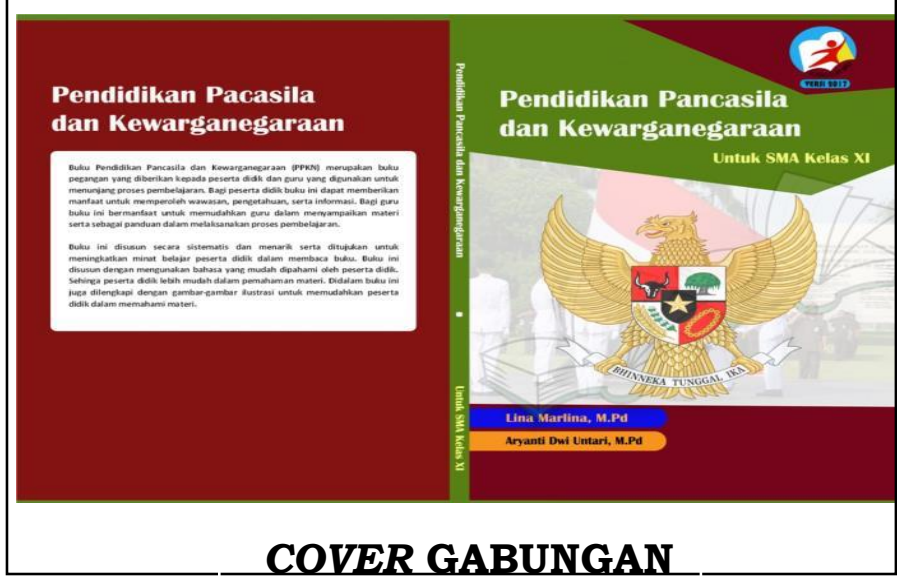

Keseluruhan aspek yang diukur rata-rata klasifikasi penilaiannya adalah kuat, maka secara keseluruhan bahan ajar ini dapat dinyatakan baik. Dari hasil analisis data dengan menggunakan instrumen angket dan setelah pengumpulan data dengan angket tertutup, maka dapat dikatakan bahwa hasil dari rekapitulasi dari daftar pertanyaan dengan jawaban Sangat Setuju (SS), Setuju (S), Tidak Setuju (TS), dan Sangat Tidak Setuju (STS). Menunjukkan hasil dengan angka kuantitatif 80.1\%. (Lihat tabel 1 pada lampiran).

Sedangkan hasil perhitungan dengan angket terbuka adalah sebagai berikut bahwa dapat dilihat $60 \%$ siswa berpendapat tampilan sampul jelas dan menarik. Hal ini menunjukkan bahwa sampul dari bahan ajar tersebut menunjukkan kejelasan dan kemenarikan siswa terhadap tampilan sampul tersebut, walapun beberapa di antaranya memilih kurang jelas tetapi menraik sebesar 30\% dan ada satu juga berpendapat jelas tapi kurang menarik hal ini menunjukkan bahwa siswa memiliki ketertarikan terhadap tampilan sampul bahan ajar tersebut. (Lihat tabel 2 pada lampiran).

Berdasarkan tabel 3 pada lampiran, dapat terlihat bahwa 50\% dari siswa berpendapat bagus dengan alasan perpduan warna yang di tampilkan sangat bagus dan menarik dan $45 \%$ siswa berpendapat cukup bagus dengan alasan warna yang ditampilkan terlihat menarik dan ada juga yang berpendapat biasa saja dengan $5 \%$ presentasenya. 
Berdasarkan tabel 4 pada lampiran menunjukkan bahwa 45\% siswa berpendapat ilustrasi bahan ajar menarik dan mewakili materi pembelajaran, dengan alasan bahwa gambar dan ilustrasi menggambarkan tentang kehidupan nyata sehari-hari, ada pula yang berpendapat menarik tapi tidak mewakili materi sebesar $35 \%$ dan $20 \%$ berpendapat biasa saja tetapi mewakili materi pembelajaran.

Berdasarkan tabel 5 pada lampiran dapat dilihat bahwa jawaban siswa sangat variatif. Terdapat 9 siswa menjawab 9 siswa dengan presentasi 45\%, 8 siswa dengan presentasi 40\%, dan 3 siswa dengan presentasi 15\% dengan alas an yang juga bervariatif, alasan siswa menjawab jelas karena materi yang diberikan ringan dan alasan menjawab cukup jelas karena Pengkajian materi cukup jelas materi dan bahan ajar sangat mudah dipahami.

Berdasarkan tabel 6 pada lampiran dapat dilihat bahwa siswa dengan jumlah 12 orang menyatakan bahwa contoh soal dan latihan menantang dengan presentase $60 \%$, dan berpendapat cukup menantang ada 2 siswa dengan presentase 10\%, dan berpendapat biasa saja 5 siswa dan dengan presentase $25 \%$, dan berpendapat tidak menantang berjumlah 1 siswa dengan presentase $5 \%$ dan dari beberapa pendapat pilihan siswa tentang contoh soal dan latihan berpendapat bahwa menantang sehingga memiliki daya tarik dan kepuasan

Berdasarkan tabel 7 pada lampiran dapat terlihat bahwa 9 siswa memilih point menarik dengan presentase 45\%, 5 siswa memilih cukup mernarik dengan jumlah presentase 25\%, dan 4 siswa memilih biasa saja dengan jumlah presentase 20\% dan merasa membosankan 2 siswa dengan presentase $10 \%$, apabila dilihat dari alasanya siswa berpendapat menarik karena dapat di pahami untuk materinya dan bila di lihat dari point terendah yaitu membosankan beralasan karena kurang paham sehingga siswa yang berjumlah 2 orang memilih jawaban membosankan.

Berdasarkan tabel 8 pada lamiran bahwa 55\% menjawab memahami dan 40\% menjawab cukup paham serta 5\% menjawab kurang paham, siswa memilih jawaban tersebut beralasan bahwa dari materi bahan ajar yang beranggapan materi yang dijelaskan sesuai dengan materinya dan yang lainnya menjawab dengan alasan Cukup memahami karena karena pelajaran PPKn membuat saya menghargai dan memahami suatu ilmu yang berguna untuk kehidupan sehari-hari. Selanjutnya berdasarkan tabel 9 pada lampiran terlihat bahwa 65\% menjawab bahwa bahan ajar sudah baik dan tidak perlu adanya perbaikan, sedangkan 35\% menjawab perlu adanya perbaikan, dengan alasan perlu adanya perbaikan warna yang lebih cerah saja.

Bahan ajar buku teks PPKn berbasis discovery learning dapat meningkatkan civic knowledge siswa kelas XI SMA Maulana Yusuf Kota Serang. Bahan ajar diperlukan oleh para guru untuk membantu menyampaikan suatu materi serta diperlukan siswa untuk mempelajari suatu materi. Oleh karena itu, diperlukan untuk mengembangkan bahan ajar agar mampu memaksimalkan pembelajaran. Apalagi guru tersebut mengunakan metode pembelajaran konvenisonal. Dengan demikian, merancang ajar buku teks PPKn berbasis discovery learning adalah bahan pengembangan bahan ajar yang efektif untuk meningkatkan dan melatih kemampuan siswa dalam melakukan analisis permasalahan yang terkandung pada tiap materi di pelajaran PPKn pada kehidupan nyata sehingga pada mata pelajaran tidak hanya sekadar pembelajaran teoretis akan tetapi dapat digunakan dalam kehidupan keseharian siswa.

Pada batasan masalah penelitian pengembangan ini bahwa pengaruh Bahan ajar buku teks PPKn berbasis discovery learning terhadap peningkatan civic knowledge siswa dilihat dari segi pandangan ahli dan respons siswa setelah menggunakan bahan ajar ini mengalami peningkatan dan berdasarkan seluruh tahapan pembangunan yang telah dilakukan, terdapat beberapa hal mengindikasikan bahan ajar ini dapat meningkatakan civic knowledge, terutama dilihat dari hasil presentase dalam angket uji ahli. Oleh karena itu ada beberapa hal yang terdapat dalam angket 
uji ahli yang secara spesifik bisa membuktikan bahwa bahan ajar ini dianggap dapat meningkatkan civic knowledge siswa menurut penilaian uji ahli. Adapun hasil dari uji ahli PPKn, ahli pendidikan serta ahli desain tentang pengaruh bahan ajar ini dapat meningkatkan civic knowledge siswa dilihat dari uaraian pembahasannya sebagai berikut yakni dalam penelitian ini yaitu uji coba pada tahap awal terciptanya produk berupa pengembangan bahan ajar buku teks PPKn berbasis discovery leraning untuk meningkatkan civic knowledge siswa SMA Maulana Yusuf Kota Serang dengan kriteria menurut ahli PPKn sebesar 67,36\%, ahli pendidikan sebesar 78\%; ahli desain 80\% dan pada uji coba pada tahap selanjutnya kriteria menurut ahli PPKn sebesar 82,10\%; ahli pendidikan sebesar 84,6\%; ahli desain 86,1\%. Dan pada uji skala terbatas yakni uji angket tertutup menunjukkan hasil dengan angka kuantitatif $80.1 \%$.

Dari hasil temuan sesuai dengan lembar wawancara siswa terhadap bahan ajar buku teks PPKn. Tahapan pengujian yang terakhir adalah melihat respon siswa setelah mendapat dan mencoba menggunakan bahan ajar ini jika melihat hasil angket tertutup pada pengujian skala terbatas mendapatkan skor akhir sebesar $80.1 \%$, skor dan hal tersebut menunjukan bahan ajar masuk dalam kategori sangat kuat sehingga dapat dikatakan bahwa respon siswa terhadap bahan ajar sangat baik. Secara khusus beberapa aspek dalam angket yang merujuk pada peningkatan civic knowledge pada siswa telah menunjukkan hasil yang positif seperti yang terdapat pada hasil angket terbuka dari delapan (8) pertanyaan yang diajukan dengan menggunakan pilihan ganda yang disertai dengan alasan siswa, bahwa dari hasil angket terbuka menjelaskan bahwa siswa memahami dan tertarik pada bahan ajar yang digunakan walaupun ada beberapa siswa lain yang berpendapat bahan ajar tersebut masih perlu perbaikan akan tetapi secara garis besar siswa dapat meningkatkan civic knowledge dengan menggunakan bahan ajar buku teks PPKn berbasis discovery leraning. Hal ini tidak jauh berbeda dengan simpulan dari penelitian Isac et.al (2011) bahwa pengetahuan dan keterampilan kewarganegaraan siswa sebagian salah satunya dipengaruhi faktor-faktor yang terkait dengan kualitas dan peluang untuk pembelajaran kewarganegaraan yang ditawarkan oleh ruang kelas dan komposisi kelas, dan oleh faktor-faktor di tingkat konteks nasional. Pendidikan kewarganegaraan (PPKn di Indonesia) haruslah melibatkan pembelajaran keterampilan sosial dan mengembangkan sosial pengetahuan dari yang ada untuk memahami dan menafsirkan isu-isu sosial yang warga negara maka siswa akan memberikan kritik sehingga menjadikan siswa sebagai warga negara yang aktif (Arthur \& Davison, 2000; Johnson \& Morris, 2010).

Pada proses pembelajaran mata pelajaran PPKn dengan menggunakan bahan ajar buku teks PPKn siswa mengalami kesulitan belajar yang dihadapi siswa pada saat proses pembelajaran yang di sampaikan atau ditugaskan oleh seorang guru, menurut (Irham \& Wiyani, 2013) mengemukakan bahwa kesulitan belajar merupakan kondisi saat siswa mengalami hambatan-hambatan tertentu untuk mengikuti proses pembelajaran dan mencapai hasil belajar secara optimal. Tiap siswa memiliki kesulitan pembelajaran yang berbeda-beda, salah satunya ada beberapa siswa yang kurang memahami materi dari bahan ajar buku teks mata pelajaran PPKn ini ada juga yang dapat langsung memahami isi dari materi dari bahan ajar tersebut hal ini dikarenakan dari segi kemampuan siswa menyerap pelajaran yang berbeda-beda tingkatannya serta adanya keberagaman individu pada tiap siswa dan kondisi lingkungan yang berbeda pula dapat menjadi salah satu faktor sehingga timbullah permasalahan yang berbeda sehingga hal tersebut menjadi salah satu hal siswa kesulitan pada saat proses pembelajaran.

\section{Simpulan}

Setelah dilakukan berbagai tahap pengembangan pada produk bahan ajar yang berbasis discovery learning, bahwa pada pengembangaan pada suatu bahan ajar buku teks pada mata 
pelajaran PPKn untuk dapat meningkatkan civic knowledge siswa harus memperhatikan beberapa hal yang penting diantaranya adalah isi dari bahan ajar tersebut, ilustrasi dari gambaran yang akan dimasukkan pada bahan ajar tersebut dan memperhatikan bahan ajar yang dapat menyampaikian pesan dari materi ajarnya dapat di aplikasikan dalam kehidupan sehari-hari nyata siswa. Pada pengembangan bahan ajar ini dilakukan pengujian bahan ajar oleh beberapa ahli serta uji coba pada skala terbatas kepada sejumlah siswa yang berperan sebagai sasaran utama dari pengembangan bahan ajar buku teks mata pelajaran PPKn ini, pada proses uji ahli dilakukan pada tiga bidang ahli yakni ahli pendidikan pancasila dan kewarganegaraan, ahli pendidikan dan ahli desain, dari ketiga ahli ini memiliki perannya masing-masing, ahli pendidikan pancasila dan kewarganegaraan melihat dari sisi kesesuaian dan keluasan bahan ajar yakni isi dari materi bahan ajar tersebut, ahli pendidikan melihat dari sisi sejauh mana pengembangan bahan ajar tersebut, dan ahli desain melihat dari sisi menilai tampilan yang digunakan pada bahan ajar. Setelah bahan uji selesai di lakukan kemudian pengembang melakukan tahap perbaikan atau tahap revisi sesuai dengan saran dan masukan yang di berikan oleh ketiga ahli tersebut. Kemudian, proses dilanjutkan degan adanya pengujian skala terbatas terhadap 20 siswa, kemudian dilakukan kembali revisi terhadap bahan ajar agar menciptakan produk akhir bahan ajar berbasis discovery learning agar dapat meningkatkan civic knowledge siswa.

\section{Ucapan Terima Kasih}

Terima kasih penulis sampaikan kepada Direktorat Riset dan Pengabdian Masyarakat Direktorat Jenderal Penguatan Riset dan Pengembangan Kementrian Riset, Teknologi dan Pendidikan Tinggi (Kemenristek Dikti) yang telah memberikan dana hibah penelitian PDP (Penelitian Dosen Pemula) dengan Surat Perjanjian Penugasan Pelaksanaan Program Penelitian berdasarkan Surat Keputusan Nomor 2689/L4/PP/2019 dan Perjanjian / Kontrak Nomor 040/LP3M-UNBAJA/V/2019. Selanjutnya, terima kasih kepada ketua dan staff LPPM Universitas Banten Jaya yang telah memfasilitasi kegiatan PDP, dan kepada pihak-pihak terkait yang telah mendukung jalannya penelitian ini mulai penyusuan proposal hingga laporan penelitian.

\section{Referensi}

Alivernini, F., \& Manganelli, S. (2011). Is there a relationship between openness in classroom discussion and students' knowledge in civic and citizenship education? Procedia - Social and Behavioral Sciences, 15, 3441-3445. https://doi.org/10.1016/j.sbspro.2011.04.315

Althof, W., \& Berkowitz, M. W. (2006). Moral education and character education: Their relationship and roles in citizenship education. Journal of Moral Education, 35(4), 495-518. https://doi.org/10.1080/03057240601012204

Arthur, J., \& Davison, J. (2000). Social literacy and citizenship education in the school curriculum. Curriculum Journal, 11(1), 9-23.

Budiningsih. (2015). Model discovery learning. Pustaka Mandiri.

Hasanah, H. (2018). Pengembangan bahan ajar cetak berbasis pendekatan problem solving untuk meningkatkan literasi matematis. GAUSS: Jurnal Pendidikan Matematika, 1(2), 137-148.

Husu, J., \& Tirri, K. (2007). Developing whole school pedagogical values-A case of going through the ethos of "good schooling." Teaching and Teacher Education, 23(4), 390-401. https://doi.org/10.1016/j.tate.2006.12.015

Irham, M., \& Wiyani, N. A. (2013). Psikologi pendidikan: Teori dan aplikasi dalam proses pembelajaran (R. K. Ratri (ed.); 2nd ed.). Ar-ruzz Media.

Isac, M. M., Maslowski, R., \& van der Werf, G. (2011). Effective civic education: An educational effectiveness model for explaining students' civic knowledge. School Effectiveness and School Improvement, 22(3), 313-333. https://doi.org/10.1080/09243453.2011.571542

Johnson, L., \& Morris, P. (2010). Towards a framework for critical citizenship education. The Curriculum 
Lina Marlina, Aryanti Dwi Untari. Pengembangan bahan ajar teks PPKn berbasis discovery learning untuk meningkatkan pengetahuan warga negara siswa sekolah mengengah atas

Journal, 21(1), 77-96. https://doi.org/10.1080/09585170903560444

Kennedy, K. J., Jimenez, S., Mayer, D., Mellor, S., \& Smith, J. (2009). Teachers ' conversations about civic education: Policy and practice in Australian schools. Asia Pacific Education Review, 3(1), 69-82. https://doi.org/10.1007/bf03024922

Mahsun. (2013). Pembelajaran teks dalam kurikulum 2013. LPPKS - Lembaga Pengembangan Dan Pemberdayaan Kepala Sekolah. http://lppks.kemdikbud.go.id/id/kabar/pembelajaran-teks-dalamkurikulum-2013

Muslich, M. (2010). Text book writing: Dasar-dasar pemahaman, penulisan, dan pemakaian buku teks. Arruz Media.

Patterson, N., Doppen, F., \& Misco, T. (2012). Beyond personally responsible: A study of teacher conceptualizations of citizenship education. Education, Citizenship and Social Justice, 7(2), 191-206.

Prastowo, A. (2011). Panduan kreatif membuat bahan ajar inovatif. Diva Press. https://doi.org/10.1016/j.burns.2014.02.013

Sanger, M. N., \& Osguthorpe, R. D. (2013). Modeling as moral education: Documenting, analyzing, and addressing a central belief of preservice teachers. Teaching and Teacher Education, 29, 167-176.

Schulz, W., Ainley, J., Fraillon, J., Kerr, D., \& Losito, B. (2009). ICCS 2009 International Report: Civic knowledge, attitudes, and engagement among lowersecondary school students in 38 countries. Amsterdam. International Association for the Evaluation of Educational Achievement.

Sugiyono. (2010). metode penelitian pendidikan pendekatan kuantitatif, kualitatif, dan R\&D. Alfabeta.

Thornberg, R. (2008). The lack of professional knowledge in values education. Teaching and Teacher Education, 24(7), 1791-1798. https://doi.org/10.1016/j.tate.2008.04.004

Torney-Purta, J., \& Barber, C. (2004). Democratic school participation and civic attitudes among European adolescents: Analysis of data from the IEA Civic Education Study. Strasborg: Council of Europe.

Widodo, C. S., \& Jasmadi. (2008). Buku panduan menyusun Bahan ajar. Elex Media Komputindo.

Wijayanti, W., \& Zulaeha, I. (2015). Pengembangan bahan ajar interaktif kompetensi memproduksi teks prosedur kompleks yang bermuatan kesantunan bagi peserta didik kelas X SMA/MA. Seloka - Jurnal Pendidikan Bahasa Dan Sastra Indonesia, 4(2), 94-101.

Willemse, T. M., ten Dam, G., Geijsel, F., van Wessum, L., \& Volman, M. (2015). Fostering teachers' professional development for citizenship education. Teaching and Teacher Education, 49, 118-127. https://doi.org/10.1016/j.tate.2015.03.008 


\section{Lampiran}

Tabel 1

Angket Tertutup Siswa Terhadap Bahan Ajar Buku Teks PPKn Berbasis Discovery Learning Untuk Meningkatkan Civic Knowledge Siswa.

\begin{tabular}{|c|c|c|c|c|c|c|}
\hline \multirow{2}{*}{ No } & \multirow{2}{*}{ Daftar Pertanyaan } & \multicolumn{4}{|c|}{ Jawaban } & \multirow{2}{*}{ Jumlah } \\
\hline & & SS & $S$ & TS & STS & \\
\hline 1 & $\begin{array}{l}\text { Saya senang belajar PPKn } \\
\text { menggunakan bahan ajar } \\
\text { ini karena penyajian materi } \\
\text { pada bahan ajar ini mudah } \\
\text { dipahami dan didasari pada } \\
\text { masalah, sehingga } \\
\text { membuat saya lebih } \\
\text { mengerti }\end{array}$ & 4 & 16 & 0 & 0 & 20 \\
\hline 2 & $\begin{array}{l}\text { Saya menjadi lebih kritis } \\
\text { dan mampu melatih } \\
\text { kemampuan untuk berfikir, } \\
\text { membuat keputusan } \\
\text { memecahkan masalah, } \\
\text { mengelola sumber daya, } \\
\text { menafsirkan informasi, dan } \\
\text { menerapkan teknologi } \\
\text { (Civic Knowledge) }\end{array}$ & 7 & 13 & 0 & 0 & 20 \\
\hline 3 & $\begin{array}{l}\text { Bahan ajar ini lebih } \\
\text { merangsang rasa } \\
\text { keingintahuan saya tentang } \\
\text { materi yang disajikan }\end{array}$ & 1 & 14 & 5 & 0 & 20 \\
\hline 4 & $\begin{array}{l}\text { Bahan ajar ini melatih } \\
\text { kemampuan saya untuk } \\
\text { dapat berpikir logis dan } \\
\text { mengaplikasikan prinsip } \\
\text { PPKn pada permasalahan } \\
\text { di dunia nyata }\end{array}$ & 8 & 11 & 1 & 0 & 20 \\
\hline 5 & $\begin{array}{l}\text { llustrasi dan gambar yang } \\
\text { digunakan pada bahan ajar } \\
\text { ini menarik dan berkaitan } \\
\text { terhadap dunia nyata }\end{array}$ & 8 & 11 & 1 & 0 & 20 \\
\hline 6 & $\begin{array}{l}\text { Latihan soal yang diberikan } \\
\text { lebih menantang, sehingga } \\
\text { memiliki daya tarik dan } \\
\text { kepuasan tersendiri untuk } \\
\text { diselesaikan }\end{array}$ & 2 & 16 & 2 & 0 & 20 \\
\hline 7 & $\begin{array}{l}\text { Saya senang mempelajari } \\
\text { bahan ajar ini karena } \\
\text { memiliki tampilan yang } \\
\text { menarik dan dinamis }\end{array}$ & 7 & 9 & 4 & 0 & 20 \\
\hline 8 & $\begin{array}{l}\text { Bahan ajar ini lebih } \\
\text { membuat saya menghargai } \\
\text { Pelajaran PPKn sebagai } \\
\text { suatu ilmu yang berguna } \\
\text { untuk kehidupan sehari- } \\
\text { hari }\end{array}$ & 9 & 11 & 0 & 0 & 20 \\
\hline
\end{tabular}




\begin{tabular}{|c|c|c|c|c|c|c|}
\hline \multirow{2}{*}{ No } & \multirow{2}{*}{ Daftar Pertanyaan } & \multicolumn{4}{|c|}{ Jawaban } & \multirow{2}{*}{ Jumlah } \\
\hline & & SS & S & TS & STS & \\
\hline 9 & $\begin{array}{l}\text { Saya lebih memiliki } \\
\text { kapasitas dan kepercayaan } \\
\text { diri untuk } \\
\text { menginterpretasikan setiap } \\
\text { prinsip Pembelajaran PPKn } \\
\text { pada kehidupan sehari-hari }\end{array}$ & 5 & 15 & 0 & 0 & 20 \\
\hline 10 & $\begin{array}{l}\text { Pembelajaran PPKn menjadi } \\
\text { lebih menarik dengan } \\
\text { menggunakan bahan ajar } \\
\text { ini }\end{array}$ & 7 & 13 & 0 & 0 & 20 \\
\hline & Total & & & & 80,1 & \\
\hline
\end{tabular}

Sumber: Data hasil penelitian, 2019.

Tabel 3

Pendapat Siswa Mengenai Tampilan Bahan Ajar

\begin{tabular}{lcc}
\hline \multicolumn{1}{c}{ Tampilan Cover } & $\begin{array}{c}\text { Jumlah } \\
\text { (Siswa) }\end{array}$ & $\begin{array}{c}\text { Presentase } \\
\%\end{array}$ \\
\hline Jelas dan Menarik & 12 & 60 \\
Kurang jelas tetepi menarik & 6 & 30 \\
Tidak jelas tetapi menarik & 1 & 5 \\
Jelas tetapi tidak menarik & 1 & 5 \\
Kurang jelas dan tidak menarik & 0 & 0 \\
Tidak jelas dan tidak menarik & 0 & 0 \\
\hline
\end{tabular}

Sumber: Data hasil penelitian, 2019.

Tabel 4

Pendapat Siswa Mengenai Kombinasi Warna

\begin{tabular}{lcc}
\hline \multicolumn{1}{c}{ Kombinasi Warna } & Jumlah & Presentase \\
& (Siswa) & $\%$ \\
\hline Bagus & 10 & 50 \\
Cukup bagus & 9 & 45 \\
Biasa saja & 1 & 5 \\
Tidak bagus & 0 & 0 \\
\hline
\end{tabular}

Sumber: Data hasil penelitian, 2019.

Tabel 5

Pendapat siswa mengenai Penggunaan Ilustrasi

\begin{tabular}{lcc}
\hline \multicolumn{1}{c}{ Ilustrasi pada bahan ajar } & $\begin{array}{c}\text { Jumlah } \\
\text { (Siswa) }\end{array}$ & $\begin{array}{c}\text { Presentase } \\
\%\end{array}$ \\
\hline $\begin{array}{l}\text { Menarik dan mewakili materi pembelajaran } \\
\text { Menarik tetapi tidak mewakili materi }\end{array}$ & 9 & 45 \\
$\begin{array}{l}\text { pembelajaran } \\
\text { Biasa saja tetapi mewakili materi }\end{array}$ & 7 & 35 \\
$\begin{array}{l}\text { pembelajaran } \\
\text { Biasa saja dan tidak mewakili materi }\end{array}$ & 4 & 20 \\
$\begin{array}{l}\text { pembelajaran } \\
\text { Tidak menarik tetapi mewakili materi }\end{array}$ & 0 & 0 \\
pembelajaran & 0 & 0
\end{tabular}




\begin{tabular}{lcc}
\multicolumn{1}{c}{ llustrasi pada bahan ajar } & $\begin{array}{l}\text { Jumlah } \\
\text { (Siswa) }\end{array}$ & $\begin{array}{c}\text { Presentase } \\
\%\end{array}$ \\
\hline $\begin{array}{l}\text { Tidak menarik dan tidak mewakili materi } \\
\text { pembelajaran }\end{array}$ & 0 & 0 \\
\hline
\end{tabular}

Sumber: Data hasil penelitian, 2019.

Tabel 6

Pendapat siswa mengenai Penyajian Materi dalam Bahan Ajar

\begin{tabular}{lcc}
\hline \multicolumn{1}{c}{ Penyajian materi } & Jumlah & Presentase \\
& (Siswa) & \% \\
\hline Jelas & 9 & 40 \\
Cukup Jelas & 8 & 15 \\
Kurang Jelas & 3 & 0 \\
Tidak Jelas & 0 & P \\
\hline
\end{tabular}

Sumber: Data hasil penelitian, 2019.

Tabel 7

Pendapat siswa mengenai Contoh Soal dan Latihan

\begin{tabular}{lcc}
\hline \multicolumn{1}{c}{ Contoh Soal dan Latihan } & Jumlah & Presentase \\
& (Siswa) & 60 \\
\hline Menantang & 12 & 10 \\
Cukup menantang & 2 & 25 \\
Biasa saja & 5 & 5 \\
Tidak menantang & 1 & \\
\hline
\end{tabular}

Sumber: Data hasil penelitian, 2019.

Tabel 8

Pendapat siswa tentang Belajar Menggunakan Bahan Ajar ini

\begin{tabular}{lcc}
\hline $\begin{array}{l}\text { Pendapat siswa terkait bahan ajar } \\
\text { yang digunakan }\end{array}$ & $\begin{array}{c}\text { Jumlah } \\
\text { (Siswa) }\end{array}$ & $\begin{array}{c}\text { Presentase } \\
\%\end{array}$ \\
\hline Menarik & 9 & 45 \\
Cukup menarik & 5 & 25 \\
Biasa saja & 4 & 20 \\
Membosankan & 2 & 10 \\
\hline
\end{tabular}

Sumber: Data hasil penelitian, 2019.

Tabel 9

Pendapat siswa mengenai pemahaman materi setelah menggunakan Bahan Ajar

\begin{tabular}{lcc}
\hline \multirow{2}{*}{ Pemahaman siswa pada bahan ajar } & $\begin{array}{c}\text { Jumlah } \\
\text { (Siswa) }\end{array}$ & $\begin{array}{c}\text { Presentase } \\
\%\end{array}$ \\
\hline Memahami & 11 & 55 \\
Cukup memahami & 8 & 40 \\
Kurang memahami & 1 & 5 \\
Tidak memahami & 0 & 0 \\
\hline
\end{tabular}

Sumber: Data hasil penelitian, 2019. 
Lina Marlina, Aryanti Dwi Untari. Pengembangan bahan ajar teks PPKn berbasis discovery learning untuk meningkatkan pengetahuan warga negara siswa sekolah mengengah atas

Tabel 10

Perbaikan dari Bahan Ajar

\begin{tabular}{lcc}
\hline \multicolumn{1}{c}{ Perbaikan dari bahan ajar } & Jumlah & Presentase \\
& (Siswa) & $\%$ \\
\hline Ada (sebutkan) & 7 & 35 \\
Tidak & 13 & 65 \\
\hline
\end{tabular}

Sumber: Data hasil penelitian, 2019. 